\title{
Sensitivity of Red Sea circulation to sea level and insolation forcing during the last interglacial
}

\author{
G. Trommer ${ }^{1,2}$, M. Siccha ${ }^{1,3}$, E. J. Rohling ${ }^{4}$, K. Grant ${ }^{4}$, M. T. J. van der Meer ${ }^{5}$, S. Schouten ${ }^{5}$, U. Baranowski ${ }^{1}$, and \\ M. Kucera ${ }^{1}$ \\ ${ }^{1}$ Department of Geosciences, University of Tübingen, Tübingen, Germany \\ ${ }^{2}$ European Institute for Marine Studies, Europole Mer, Plouzané, France \\ ${ }^{3}$ Institute of Earth Sciences, Hebrew University of Jerusalem, Jerusalem, Israel \\ ${ }^{4}$ National Oceanography Centre, University of Southampton, Southampton, UK \\ ${ }^{5}$ Department of Marine Organic Biogeochemistry, NIOZ Royal Netherlands Institute \\ for Sea Research, Den Burg, Texel, The Netherlands
}

Received: 9 March 2011 - Published in Clim. Past Discuss.: 8 April 2011

Revised: 30 July 2011 - Accepted: 15 August 2011 - Published: 30 August 2011

\begin{abstract}
This study investigates the response of Red Sea circulation to sea level and insolation changes during termination II and across the last interglacial, in comparison with termination I and the Holocene. Sediment cores from the central and northern part of the Red Sea were investigated by micropaleontological and geochemical proxies. The recovery of the planktic foraminiferal fauna following high salinities during marine isotopic stage (MIS) 6 took place at similar sea-level stand ( $\sim 50 \mathrm{~m}$ below present day), and with a similar species succession, as during termination I. This indicates a consistent sensitivity of the basin oceanography and the plankton ecology to sea-level forcing. Based on planktic foraminifera, we find that increased water exchange with the Gulf of Aden especially occurred during the sea-level highstand of interglacial MIS 5e. From MIS 6 to the peak of MIS 5e, northern Red Sea sea surface temperature (SST) increased from $21^{\circ} \mathrm{C}$ to $25^{\circ} \mathrm{C}$, with about $3{ }^{\circ} \mathrm{C}$ of this increase taking place during termination II. Changes in planktic foraminiferal assemblages indicate that the development of the Red Sea oceanography during MIS 5 was strongly determined by insolation and monsoon strength. The SW Monsoon summer circulation mode was enhanced during the termination, causing low productivity in northern central Red Sea core KL9, marked by high abundance of $G$. sacculifer, which - as in the Holocene - followed summer insolation. Core KL11 records the northern tip of the intruding intermediate water layer from the Gulf of Aden and its planktic foraminifera fauna shows evidence for elevated productivity during the sea-level highstand in the southern central Red Sea. By the time of MIS 5 sea-level regression, elevated or-
\end{abstract}

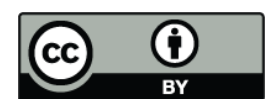

Correspondence to: $\mathrm{G}$. Trommer (gabi.trommer@gmx.de) ganic biomarker BIT values suggest denudation of soil organic matter into the Red Sea and high abundances of $G$. glutinata, and high reconstructed chlorophyll- $a$ values, indicate an intensified NE Monsoon winter circulation mode. Our results imply that the amplitude of insolation fluctuations, and the resulting monsoon strength, strongly influence the Red Sea oceanography during sea-level highstands by regulating the intensity of water exchange with the Gulf of Aden. These processes are responsible for the observation that MIS $5 \mathrm{e} / \mathrm{d}$ is characterized by higher primary productivity than the Holocene.

\section{Introduction}

The Red Sea is an ideal natural laboratory to investigate the interplay between sea-level rise and atmospheric forcing during and after terminations, due to its sensitivity to sea-level fluctuations (Winter et al., 1983; Locke and Thunell, 1988; Thunell et al., 1988; Rohling and Zachariasse, 1996; Rohling et al., 1998, 2008a, b; Fenton et al., 2000; Siddall et al., 2003, 2004) and to monsoon-driven oceanographic changes (Almogi-Labin et al., 1991; Hemleben et al., 1996; Biton et al., 2010; Trommer et al., 2010). The restricted connection to the Indian Ocean, the Strait of Bab-el-Mandeb in the south, and high evaporation rates over the entire basin (Sofianos et al., 2002) determine the water exchange with the Gulf of Aden, which results in a characteristic circulation pattern and a strong gradient of environmental parameters along the basin axis (Weikert et al., 1987; Siccha et al., 2009). Today, the exchange with the Gulf of Aden alternates seasonally between a three-layer mode during the summer SW Monsoon and a two-layer mode during the winter NE

Published by Copernicus Publications on behalf of the European Geosciences Union. 
Monsoon (Smeed, 1997, 2004). In winter, a wind driven surface water layer enters the basin from the south (Patzert, 1974), whereas in summer, nutrient enriched Gulf of Aden waters enter the basin in an intermediate layer (Souvermezoglou et al., 1989). Evaporation rates in the Red Sea reach $\sim 2 \mathrm{~m} \mathrm{a}^{-1}$ in the north of the basin, which is reflected by high salinities and relatively cool surface water conditions (Sofianos et al., 2002). Overall, the circulation system of the Red Sea is anti-estuarine and driven by thermohaline forcing with deep water formation in the northern Gulfs (Cember, 1988; Eshel et al., 1994; Sofianos and Johns, 2002, 2003; Manasrah et al., 2004). Large parts of the Red Sea experience highest primary productivity during the winter (Veldhuis et al., 1997; Siccha et al., 2009), except for the very southern Red Sea, which is influenced by the inflow of the nutrient-rich intermediate water from the Gulf of Aden during the summer (Smeed, 1997).

Since the circulation and water exchange system are primarily dependent on sea level (Siddall et al., 2003, 2004; Biton et al., 2008), the abundance of planktic foraminifera reflects in first instance salinity conditions (Winter et al., 1983; Locke and Thunell, 1988; Thunell et al., 1988; Fenton et al., 2000). The sea-level dependent recovery of the planktic fauna after termination I was investigated for several organism groups (Winter et al., 1983; Almogi-Labin et al., 1991; Legge et al., 2006; Trommer et al., 2010), and an analysis of the salinity sensitive planktic foraminifera revealed that sea level must have risen to less than $50-55 \mathrm{~m}$ below the presentday level to allow establishment of a "normal" marine plankton community (Trommer et al., 2010). It has been further inferred that during the Holocene sea-level highstand, atmospheric forcing became a key control on the circulation system throughout the Red Sea (Biton et al., 2010; Trommer et al., 2010). In addition, it has been found that the Indian Monsoon exerted an important influence on Red Sea oceanography and its planktic communities (Hemleben et al., 1996) due to changes in nutrient availability (Siccha et al., 2009; Trommer et al., 2010) and stratification of the water column (Almogi-Labin et al., 1991).

Compared to present-day and Holocene conditions, the Last Interglacial or marine isotopic stage (MIS) 5e was characterised by unusually high summer insolation, resulting in global temperatures up to $2{ }^{\circ} \mathrm{C}$ higher than today (OttoBliesner et al., 2006; Jouzel et al., 2007) and significantly reduced continental ice volume (Anklin et al., 1993; Cuffey and Marshall, 2000; Lambeck and Chappell, 2001; OttoBliesner et al., 2006; Rohling et al., 2008b; Kopp et al., 2009). Sea-level reconstructions suggest that during termination II, sea level rose in two steps with similar rates as during termination I (Siddall et al., 2003, 2006; Rohling et al., $2008 \mathrm{~b}$ ), reaching a mean level at $4-6 \mathrm{~m}$ above the present, with potential peaks up to $8 \pm 1 \mathrm{~m}$ (Plaziat et al., 1995; McCulloch and Esat, 2000; Orszag-Sperber et al., 2001; Siddall et al., 2006; Rohling et al., 2008b; Kopp et al., 2009; Muhs et al., 2011). As a consequence of the strong sum- mer insolation, intensified monsoonal conditions with levels of rainfall exceeding that observed during the corresponding early Holocene insolation maximum are recorded from regions reflecting the African Monsoon (Rossignol-Strick, 1983; Rohling et al., 2004; Weldeab et al., 2007), the Asian Monsoon (Wu et al., 2002; Chen et al., 2003; Yuan et al., 2004; Wang et al., 2008), and the Indian Monsoon (Van Campo et al., 1982; Clemens et al., 1991). The high summer insolation seems to have led to a northward shift of monsoonal rainfall as recorded by speleothems in Oman (Burns et al., 1998, 2001; Fleitmann et al., 2003) and Mediterranean sapropels (Rohling et al., 2002; Osborne et al., 2008). Model simulations also indicate shifts of zonal moisture transport during this time period (Montoya et al., 2000; Herold and Lohmann, 2009).

However, it remains to be established to what extent, and according to what relationships, the more intense monsoon and higher sea level of MIS 5e affected the Red Sea oceanography. To provide answers, we investigate termination II (which had similar rates of sea-level rise as termination I; Siddall et al., 2003, 2006; Rohling et al., 2008b) and MIS 5e, when summer insolation was enhanced and sea level stood higher relative to the Holocene. For this purpose, we present new high-resolution micropaleontological data from marine sediment cores in the Red Sea, along with organic geochemical data. Primary productivity, an indicator of circulation modes in the Red Sea (Veldhuis et al., 1997), is estimated using planktic foraminiferal transfer functions (Siccha et al., 2009). Sea surface temperature (SST) is reconstructed for the northern Red Sea using the TEX 86 proxy (TetraEther Index of ketones with 86 carbon atoms (Schouten et al., 2002), with a Red Sea-specific calibration (Trommer et al., 2009). The $\mathrm{TEX}_{86}$ is at present the only available method to estimate SST in the Red Sea, as Mg/Ca (Hoogakker et al., 2009) and $\delta^{18} \mathrm{O}$ of planktic foraminifera (e.g. Locke and Thunell, 1988) are influenced by salinity and alkenones are only present in sufficient amounts in the very north of the Red Sea. The $\mathrm{TEX}_{86}$ is based on glycerol dialkyl glycerol tetraether (GDGT) membrane lipids of marine Crenarchaeota, which are widespread in open ocean settings (Fuhrman et al., 1992; Hoefs et al., 1997; Schouten et al., 2000; Sinninghe Damsté et al., 2002; Herndl et al., 2005). Recent investigations suggest that the Red Sea may harbour an endemic population of Crenarchaeota with a specific $\mathrm{TEX}_{86}$ vs. SST relationship (Trommer et al., 2009). Today, this endemic Crenarchaeota population occurs in the central and southern Red Sea together with the open ocean population (Kim et al., 2008, 2010) that enters the basin from the south, which results in a mixture of two different GDGT signals in the southern and central Red Sea (Trommer et al., 2009). We use this mixed GDGT signal in the central Red Sea to estimate the exchange rate with the Gulf of Aden relative to modern conditions, based on a simple two end-member mixing model (Biton et al., 2010). 


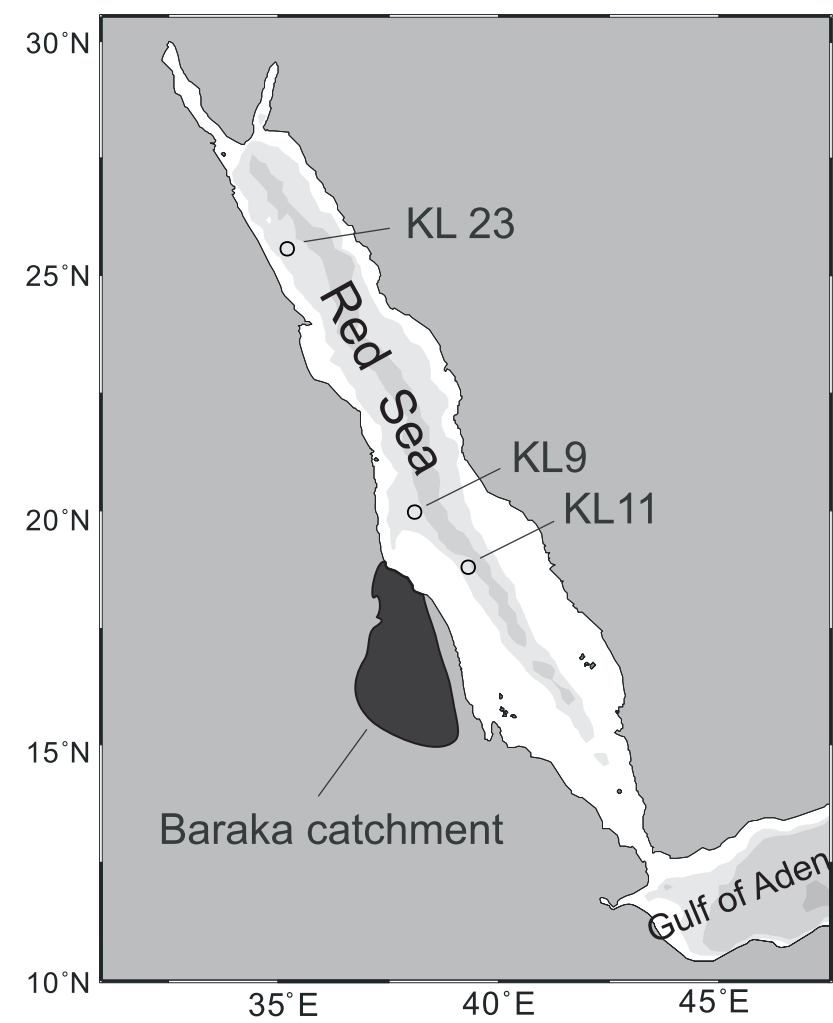

Fig. 1. Map of the Red Sea with the investigated cores KL23 (Geiselhart, 1998; Schmelzer, 1998), KL9, and KL11, highlighting the position of the seasonally active Baraka catchment.

\section{Material and methods}

In order to detect shifts in the circulation pattern and corresponding changes in primary productivity in the Red Sea, planktic foraminiferal faunal assemblages were investigated from two marine sediment cores in the central Red Sea (Meteor cruise M5/2, piston core GeoTüKL9, $19^{\circ} 57.6^{\prime} \mathrm{N}, 38^{\circ} 06.3^{\prime} \mathrm{E}$, and piston core GeoTü-KL11, $18^{\circ} 45.6^{\prime} \mathrm{N}, 39^{\circ} 21.3^{\prime} \mathrm{E}$, Fig. 1).

The core section of KL9 corresponding to MIS 5dMIS 6 (387 cm-510 cm, 107-148 ka BP, see also Rohling et al. (2008a, b)) was sampled in $1 \mathrm{~cm}$ resolution and individual samples $(n=77)$ were dried, weighed, and washed over a $>63 \mu \mathrm{m}$ mesh; dried again, sieved over $>150 \mu \mathrm{m}$, and split with an ASC Scientific microsplitter. For KL11, the $>150 \mu \mathrm{m}$ fraction of existing samples $(653 \mathrm{~cm}-700 \mathrm{~cm}$, Schmelzer (1998)) was analysed and combined with newly taken additional samples $(620 \mathrm{~cm}-653 \mathrm{~cm})$, which were processed as for KL9. Altogether a total of 77 samples were analysed for KL11. Where possible, aliquots containing at least 300 planktic foraminifera were counted and identified to species level, following the taxonomy of Hemleben et al. (1989). Existing micropaleontological data (size fraction $>250 \mu \mathrm{m})$ from a sediment core in the northern Red
Sea (KL23, $25^{\circ} 44.9^{\prime} \mathrm{N}, 35^{\circ} 03.3^{\prime}$ E, Fig. 1, Geiselhart (1998), Schmelzer (1998)) were used to compare trends in faunal community composition along the basin axis in order to determine which changes occurred in the entire Red Sea, possibly reflecting the influence of variability in the Indian Monsoon system. Additionally, we applied for the central Red Sea cores several transfer function approaches (see Siccha et al., 2009) to reconstruct chlorophyll- $a$ concentrations in surface waters based on the planktic foraminiferal assemblage composition in the sediments. To this end, we used the software C2 (Juggins, 2003) and performed transfer functions with the Weighted Average-Partial Least Square (WA-PLS) method, the Modern Analogue Technique (MAT), and the Imbrie and Kipp method (IKM). Analogy of the fossil assemblages to modern ones was tested by applying a principal component analysis (PCA) on log-transformed faunal data after removal of species with total overall abundances $<1 \%$ (Siccha et al., 2009). In the Red Sea, the analogy of foraminifera assemblages reflects oceanographic conditions, in particular with respect to circulation patterns and salinity, which are comparable to modern oceanographic conditions (Siccha et al., 2009). Only under such analogue circumstances do the applied transfer functions produce reliable reconstructed chlorophyll- $a$ values.

In addition to the faunal counts, the abundance of GDGT membrane lipids of marine Crenarchaeota were analysed in sediment samples from cores KL9 $(n=15)$ and KL23 $(n=15)$. The northern Red Sea core KL23 is well suited for reconstructing SST by applying the $\mathrm{TEX}_{86}$ proxy with the Red Sea calibration (Trommer et al., 2009). In the central Red Sea, $\mathrm{TEX}_{86}$ can potentially be used to detect changes in the mixing regime during the termination between the endemic Red Sea GDGT signal and the intruding Gulf of Aden water carrying an open ocean GDGT signal. In addition to the $\mathrm{TEX}_{86}$, the BIT (Branched Isoprenoid Tetraether) index (Hopmans et al., 2004) can be derived from GDGT analyses that include the soil derived branched tetraether lipids (Hopmans et al., 2004). The BIT index is used as an indicator for the relative contribution of soil organic matter (Kim et al., 2006; Weijers et al., 2006; Walsh et al., 2008) transported into the Red Sea in the past. Today, the surrounding desert conditions and the lack of large rivers draining into the basin do not suggest a large input of soil derived GDGTs, as shown by low BIT values $(<0.1)$ in the Red Sea surface sediments (Trommer et al., 2009).

For the extraction of GDGTs, at least $8 \mathrm{~g}$ of sediment were freeze-dried and homogenized before being extracted with an accelerated solvent extractor (ASE 200, Dionex) using dichloromethane (DCM)/MeOH, 9:1 (v:v) at $100^{\circ} \mathrm{C}$ and $7.6 \times 10^{6} \mathrm{~Pa}$. For GDGT analyses, the extract was dried under $\mathrm{N}_{2}$, separated in an apolar and polar fraction, the polar fraction was re-dissolved in hexane/isopropanol (99:1) and filtered before performing high performance liquid chromatography (HPLC) atmospheric pressure chemical ionization (APCI) mass spectrometry (MS), according to Hopmans 


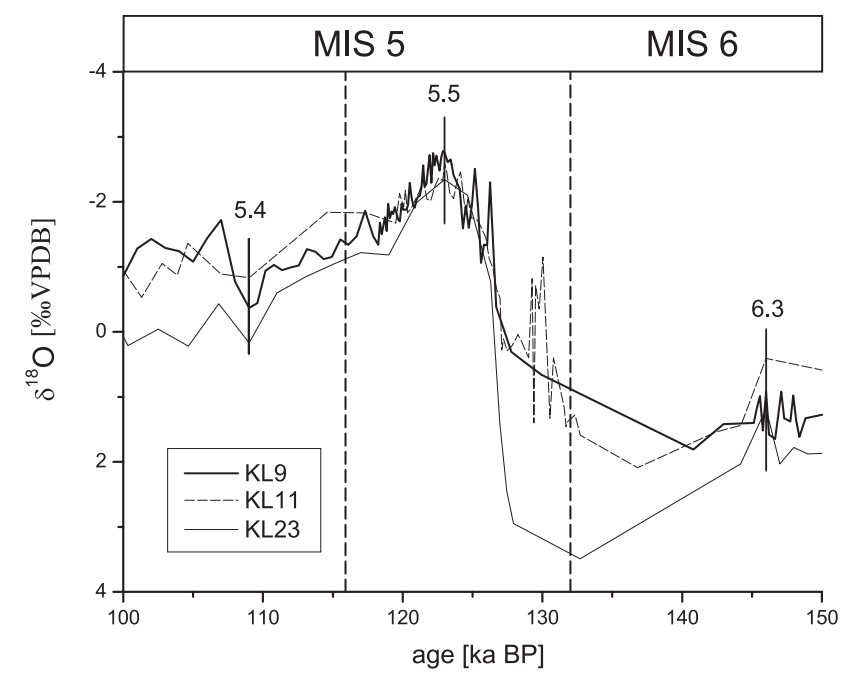

Fig. 2. Age models of the sediment cores used in this study: $\delta^{18} \mathrm{O}$ records from KL9 and KL11 (data from Rohling et al. (2008b)) and KL23 (data from Badawi et al. (2005)) (control points 6.3, 5.5 and 5.4 as indicated by vertical lines). Dashed vertical lines mark the MIS 5e/d (116 ka BP) and MIS 6/5e boundary (132 ka BP, Shackleton et al., 2003).

et al. (2000) and Schouten et al. (2007). Areas of GDGTs in mass chromatograms were manually integrated and the TEX $_{86}$ index was calculated after Schouten et al. (2002), where GDGTs 1-3 represent GDGTs with 1-3 cyclopentane moieties, respectively, and GDGT 4' represents the regioisomer of crenarchaeol:

$$
\mathrm{TEX}_{86}=\frac{[\text { GDGT2 }]+[\text { GDGT3 }]+\left[\mathrm{GDGT}^{\prime}\right]}{[\text { GDGT1 }]+[\mathrm{GDGT} 2]+[\mathrm{GDGT} 3]+\left[\mathrm{GDGT}^{\prime}\right]}
$$

For the northern Red Sea core KL23, TEX 86 values were used to reconstruct SST by applying the northern Red Sea calibration of Trommer et al. (2009):

$\mathrm{SST}=\left(\mathrm{TEX}_{86}+0.09\right) / 0.035$

The BIT index is based on the relative abundance of branched GDGTs representing soil organic matter, and crenarchaeol representing aquatic organic matter, and is defined as:

$$
\text { BIT }=\frac{[\text { GDGT5 }]+[\text { GDGT6 }]+[\text { GDGT7 }]}{[\text { GDGT5] }+[\text { GDGT6 }]+[\text { GDGT7 }]+[\text { GDGT4 }]}
$$

With GDGT 5-7 being the soil derived branched GDGTs with 4-6 methyl groups and GDGT 4 being crenarchaeol, the biomarker for Crenarchaeota (Hopmans et al., 2004).

\section{Results}

\subsection{Age model}

For the age model development, oxygen isotope data for KL23 (Badawi et al., 2005) and high resolution data for
KL9 and KL11 (Rohling et al., 2008b) were correlated. Recently, Rohling et al. (2009) correlated a high resolution $\delta^{18} \mathrm{O}$ record of KL9 with the Antarctic Temperature anomaly $\left(\Delta \mathrm{T}_{\mathrm{AA}}\right)$ record (Jouzel et al., 2007). However, to maintain our records comparable with other studies from the Red Sea, the Gulf of Aden, and the latest sea-level study on the last interglacial (Kopp et al., 2009), we have used the age model of Rohling et al. (2008b). Since there is no scientific concordance about the exact stratigraphic location of the MIS 5e boundaries (Shackleton et al., 2003) or their ages (e.g., Imbrie et al., 1984; Winograd et al., 1992; Henderson and Slowey, 2000; Thompson and Goldstein, 2005; Thomas et al., 2009), the boundaries are not used for developing the age model, but are indicated only for visual orientation in the graphics. Following Lisiecki and Raymo (2005) and Rohling et al. (2008b), sea-level maximum was set at $123 \mathrm{ka} \mathrm{BP}$ and other control points were defined by visual correlation of the benthic foraminiferal $\delta^{18} \mathrm{O}$ record of Lisiecki and Raymo (2005) and the SPECMAP $\delta^{18}$ O record (Imbrie et al., 1984, Table 1, Fig. 2). The simple age model for relative comparison of the Red sea cores was derived by linear interpolation between these control points.

\subsection{Planktic foraminiferal analyses}

We observed a total of 24 species in KL9 (22 in KL11), of which 17 occur at least once with relative abundance $>1 \%$. The assemblage is dominated by eight species, which make up $>97 \%$ (>90\% in KL11) of the fauna: Globigerinita glutinata, Globigerinella calida, Globigerinella siphonifera, Globigerinoides ruber, Globigerinoides sacculifer, Globoturborotalita rubescens, Globoturborotalita tenella, and Tenuitella parkerae. Concerning the species G. ruber, in KL11 occasionally the pink variety was found $(\sim 1.5 \%$ of all G. ruber $)$ until $\sim 125 \mathrm{ka} \mathrm{BP}$, and in KL9 only specimens of the white variety were found. The pink variety is known to have survived in the Indian Ocean until about $120 \mathrm{ka}$ BP ago (Thompson et al., 1979). The foraminiferal fauna of the two cores (Fig. 3) resembles that of the nearby core MD1017 (Fenton et al., 2000) and shows similarities to KL23 (Fig. 3, Schmelzer (1998); Geiselhart (1998)).

The glacial MIS 6 is only represented by three samples of KL9. The following seven samples in KL9 (and the first nine samples of KL11) originate from an "aplanktonic zone" (Fenton et al., 2000), where the total number of planktic foraminifera was below 300 per sample $\left(1.6 \mathrm{~cm}^{3}\right.$ sediment). Up to the aplanktonic zone, G. ruber dominates the foraminiferal fauna, while G. glutinata reaches higher abundances at the boundary of the aplanktonic zone. At termination II, the transition into MIS 5e, absolute foraminiferal numbers increase faster in KL11 than in KL9 and G. sacculifer is the leading species during the reestablishment of the foraminiferal fauna in the central to northern Red Sea (Fig. 3). The period of reestablishment lasts until $\sim 126$ $127 \mathrm{ka}$ BP, when absolute abundances reach values similar 
Table 1. Age model tie points of the observed Red Sea cores.

\begin{tabular}{lllll}
\hline $\begin{array}{l}\text { KL23 core } \\
\text { depth }(\mathrm{cm})\end{array}$ & $\begin{array}{l}\text { KL9 core } \\
\text { depth }(\mathrm{cm})\end{array}$ & $\begin{array}{l}\text { KL11 core } \\
\text { depth }(\mathrm{cm})\end{array}$ & age (ka BP) & Reference \\
\hline 660 & 392.25 & 613 & 109 & 5.4 Lisiecki and Raymo (2005) \\
730 & 451.25 & 663 & 123 & $\begin{array}{l}\text { 5.5 Rohling et al. (2008b); } \\
\text { Lisiecki and Raymo (2005) }\end{array}$ \\
870 & 504.25 & 753 & 146 & 6.3 Imbrie et al. (1984) \\
\hline
\end{tabular}

to those after termination I (Trommer et al., 2010), indicating that the surface salinity was within tolerance limits of all registered species. Highest planktic foraminiferal abundances occur before the sea-level maximum in KL11 at $\sim 125 \mathrm{ka} \mathrm{BP}$ and $\sim 2.5 \mathrm{ka}$ later in KL9, and in each case the three main species (G. glutinata, G. ruber, and G. sacculifer) occur in more or less equal numbers. After the absolute abundance maxima, G. glutinata dominates the foraminiferal fauna for the next $12 \mathrm{ka}$ in KL9, reaching a second absolute abundance maximum at $\sim 116.5 \mathrm{ka} \mathrm{BP}$ and remaining the dominant species until the end of the record in KL11. G. ruber shows similar trends as G. glutinata, whereas G. sacculifer almost completely vanishes. At the end of the KL9 record, G. glutinata abundances break down and G. ruber dominates a depauperate assemblage with low total numbers, indicating rising salinity due to sea-level lowering.

The general trend for G. ruber and G. sacculifer can also be observed in the $>250 \mu \mathrm{m}$ fraction counts from KL23 (Fig. 3). G. sacculifer is dominating the foraminiferal fauna after termination II, followed by $G$. ruber, which reaches maximum abundances at $\sim 116 \mathrm{ka} \mathrm{BP}$. G. glutinata is present in very low abundances in the northern Red Sea today (Siccha et al., 2009), but due to the analysed large size fraction in KL23 this small species is likely to be underrepresented in the counts from this core. Between $\sim 112$ and $106 \mathrm{ka} \mathrm{BP}$, G. sacculifer takes over as most abundant species in KL23, whereas $G$. ruber and G. glutinata continue to dominate the assemblage in central Red Sea cores (Fig. 3).

\subsection{Reconstruction of surface productivity using foraminiferal transfer functions}

To ensure the correct interpretation of the applied transfer functions, the analysed fossil foraminiferal assemblages of KL9 and KL11 were tested for analogy with modern assemblages by a common PCA with the calibration data set used by Siccha et al. (2009). Analogue conditions are indicated by overlapping PCA component values and were found for samples between approximately $\sim 129-121 \mathrm{ka} \mathrm{BP}$ and $\sim 112-108 \mathrm{ka}$ BP in KL9 (Fig. 4a), and from 127-121 ka in KL11 (not shown). Calculated Bray-Curtis-dissimilarities values for all samples of the analogue periods in both cores were smaller than 0.15 , which is well below the commonly

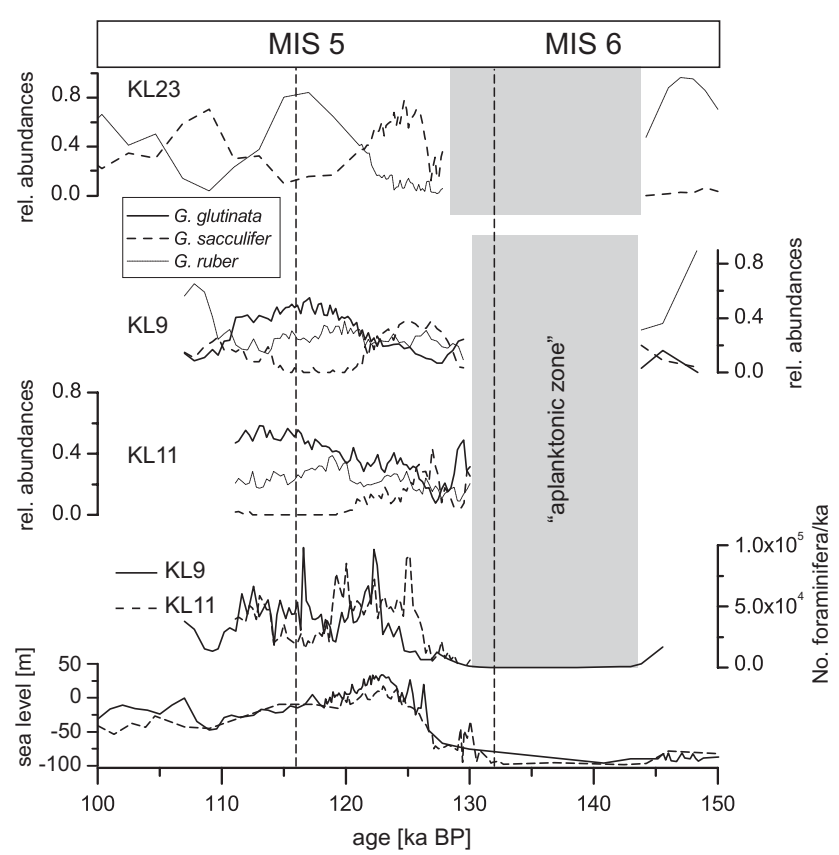

Fig. 3. Relative abundances of the dominant planktic foraminifera species in KL23 (Geiselhart, 1998; Schmelzer, 1998), KL9 and KL11 (data from this study); their absolute abundances in KL9 and KL11 and sea-level reconstructions from oxygen isotopes (Rohling et al., 2008b based on Siddall et al., 2004) for the investigated interval. Grey bars indicate "aplanktonic zone" (Fenton et al., 2000). Dashed vertical lines mark the MIS 5e/d (116 ka BP) and MIS 6/5e boundary (132 ka BP, Shackleton et al., 2003).

used thresholds for the application of transfer functions (e.g. Overpeck et al., 1985; Gersonde et al., 2005; Siccha 2009). Non-analogue conditions in both cores were determined for glacial conditions and high $G$. glutinata abundances. At present, high abundances of G. glutinata are observed in the southern Red Sea (Auras-Schudnagies et al., 1989; Siccha et al., 2009), but the difference between MIS 6/5d and the calibration data set most likely derives from the continuous presence of $G$. tenella in the MIS 6/5d samples. G. tenella is found in core top samples only in the northern Red Sea (Siccha et al., 2009) and is almost absent in regions were G. glutinata is present, causing non-analogue conditions between 

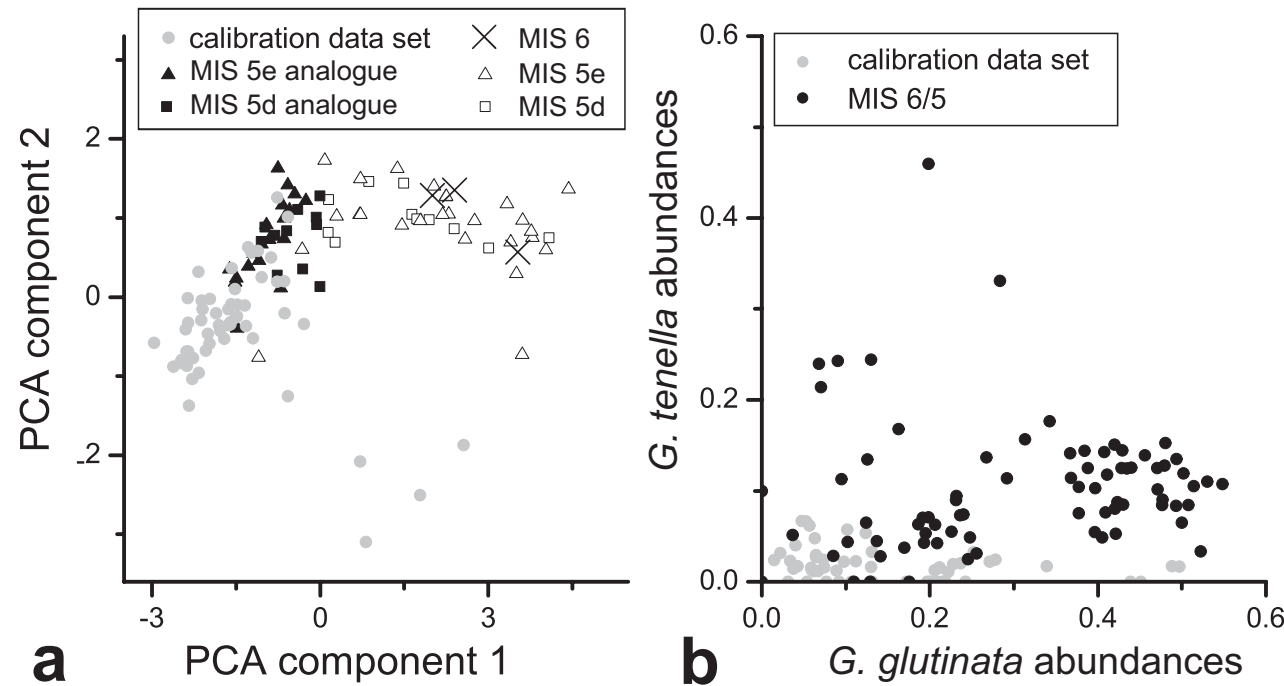

Fig. 4. Comparison of KL9 foraminiferal faunal assemblage data of MIS 6-5d and the calibration data set (grey filled circles). Left: analogy analyses of the most abundant species (according to Siccha et al., 2009). Plotted is PCA component 1 vs. PCA component 2. Black symbols indicate samples from the periods $\sim 129-121 \mathrm{ka} \mathrm{BP}$ and $\sim 112-108 \mathrm{ka} \mathrm{BP}$, which are considered as analogous to modern samples. Open symbols indicate non-analogue samples. Right: G. glutinata vs. G. tenella relative abundances.

MIS 6/5d to the calibration data set (Fig. 4b). It is not known under which specific conditions $G$. tenella thrives and it must be concluded that absolute reconstructed chlorophyll- $a$ values of the transfer functions are not reliable during the period that has no modern analogue.

All applied transfer functions (MAT-, WA-PLS-, and IKM-approaches) on the foraminiferal assemblages of the observed period displayed the same trends in productivity, which is why we show only the WA-PLS results (best performance after Siccha et al. (2009), Fig. 5b). During termination II, when $G$. sacculifer reaches maximum abundances (Fig. 5c), reconstructed chlorophyll- $a$ values are low, mostly below the present day value at the core position in the central Red Sea (Fig. 5b). With increasing G. glutinata abundances, reconstructed chlorophyll- $a$ values increase, reaching modern productivity conditions in the central Red Sea between $127-125 \mathrm{ka}$ BP. The increasing productivity trend continues, following the increase in G. glutinata and decrease in $G$. sacculifer, until chlorophyll- $a$ values return to modern conditions in KL9 at $\sim 110 \mathrm{ka}$ BP. Absolute values between 121-112 ka BP are not reliable due to the lack of present day faunal analogues, but the high abundance of G. glutinata indicates that productivity was higher than today and during the Holocene (Trommer et al., 2010) in the central Red Sea, as this species is often associated with elevated productivity (Cullen and Prell, 1984; Naidu and Malmgren, 1996; Schulz et al., 2002).

\subsection{TEX $\mathrm{X}_{86}$ and BIT index}

The $\mathrm{TEX}_{86}$ increases in both cores from glacial to interglacial (Fig. 6b), while KL23 shows generally lower TEX 86 values than KL9, which is consistent with recent temperature differences in the northern compared to in the central Red Sea (Conkright et al., 2001). TEX 86 values from KL9 range from 0.68 to 0.86 and for KL23 from 0.63 to 0.79 . From $\sim 129$ to $125 \mathrm{ka} \mathrm{BP}$, a steep increase in the TEX 86 of KL23 is observed, which coincides with the decrease in foraminiferal $\delta^{18} \mathrm{O}$ during the termination (Fig. 6).

In contrast to the $\mathrm{TEX}_{86}$ trends, the BIT indices of the core records of KL23 and KL9 show strong fluctuations (Fig. 6c). During the MIS $6 / 5$ transition, the BIT values are relatively low $(0-0.2)$, and they rise in both cores to around $0.45-0.55$ in the latter part of MIS 5e. In KL9 an earlier maximum can be observed during the glacial, around $\sim 145 \mathrm{ka} \mathrm{BP}$. At present, BIT values in subsurface sediments throughout the Red Sea are lower than 0.1 (Trommer et al., 2009), and the observed peak values during MIS 5e are comparable with coastal marine sediments in, e.g. the Mediterranean Sea, where significant amounts of soil organic matter is supplied through fluvial transport (Kim et al., 2006, 2010). An enhanced input of soil organic matter (SOM) can potentially influence the $\mathrm{TEX}_{86}$. But since there is no conspicuous total organic carbon maximum recorded from this time in the central Red Sea (Rohling et al., 1998) and there does not seem to be a consistent change in $\mathrm{TEX}_{86}$ coinciding with the change in BIT, it seems that the $\mathrm{TEX}_{86}$ is not biased to a large degree by influx of SOM in the Red Sea. 


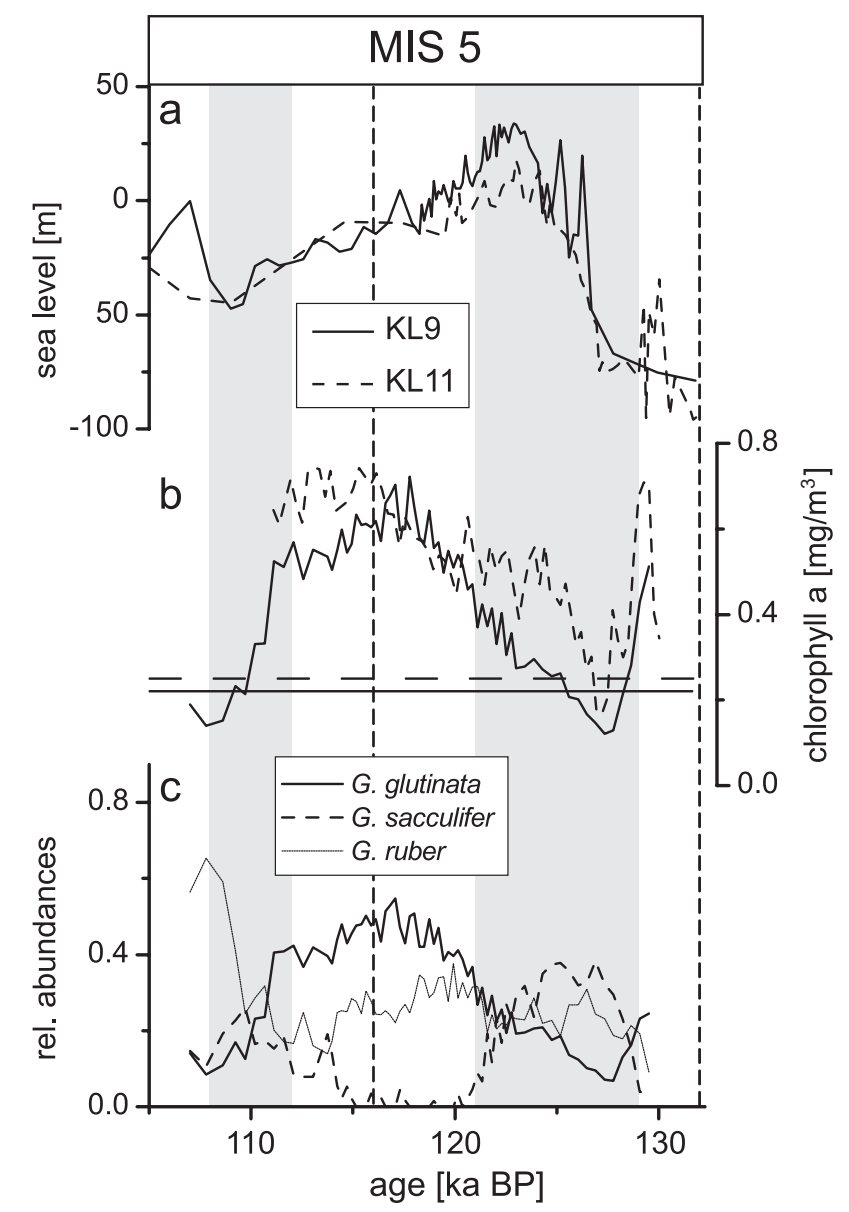

Fig. 5. (a) Sea-level reconstructions from KL9 and KL11 oxygen isotopes (Rohling et al., 2008b) based on Siddall et al. (2004), (b) KL9 and KL11 chlorophyll- $a$ reconstructions by the WA-PLS transfer functions approach, and (c) KL9 relative abundances of the three most abundant species: G. glutinata, G. ruber, and G. sacculifer. Grey bars indicate approximate analogue to present-day periods (112-108 ka BP only for KL 9). Dashed vertical lines mark MIS-boundaries.

Therefore, we use the $\mathrm{TEX}_{86}$ in the northern Red Sea core KL23 to estimate SST with the recently developed Red Sea TEX $_{86}$ calibration (Trommer et al., 2009). Calculated SSTs indicate a SST increase from 21 to $25^{\circ} \mathrm{C}\left( \pm 0.5^{\circ} \mathrm{C}\right.$, combined analytical (Schouten et al., 2007) and calibration error (Trommer et al., 2009)) from the glacial to interglacial, with a possible minor SST peak of $24.5^{\circ} \mathrm{C}$ shortly before the $\delta^{18} \mathrm{O}$ minimum/sea-level maximum (Fig. 6b). SST can not be directly inferred from the Red Sea TEX 86 calibration in KL9, as this core lies in an area which is considered to be influenced by an open ocean GDGT signal advected from the open ocean during interglacials (Trommer et al., 2009). In the discussion, we therefore explore whether the central Red Sea TEX 86 signal can be interpreted as a relatively pure (endemic) SST signal during glacials, and as a mixture of

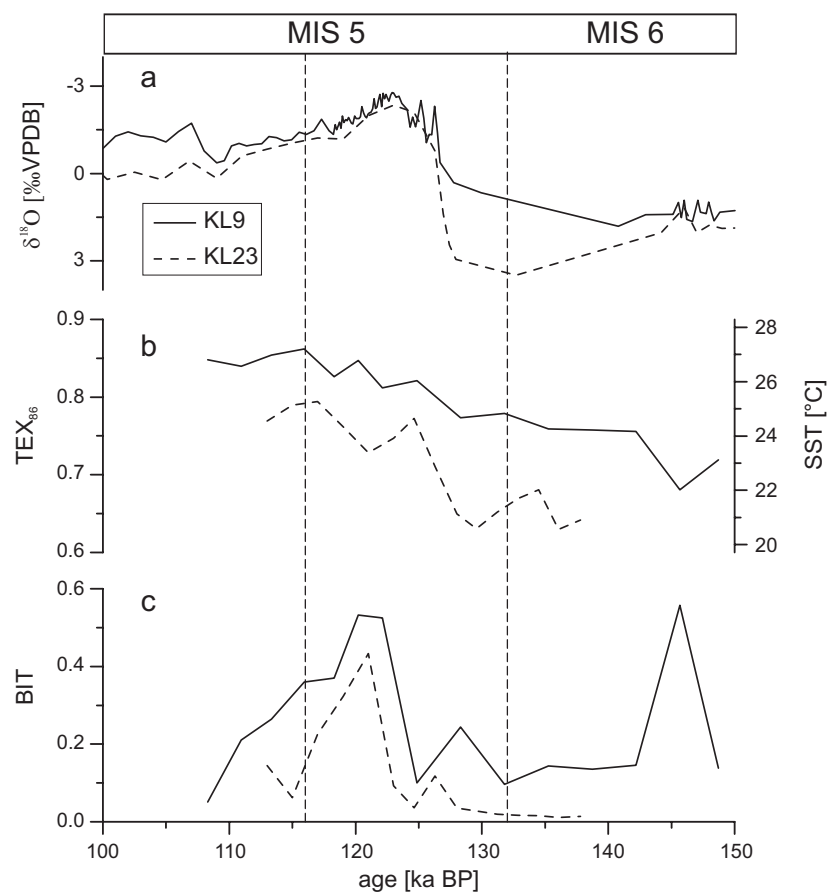

Fig. 6. Geochemical data of cores KL9 and KL23: (a) oxygen isotopes (KL23 (Geiselhart, 1998) and KL9 (Rohling et al., 2008b)), (b) $\mathrm{TEX}_{86}$ (SST scale is only valid for KL23, see discussion in Sect. 4.1, and (c) BIT values. Dashed vertical lines mark MISboundaries.

(endemic) Red Sea and (advected) open-ocean signals during the termination and interglacial.

\section{Discussion}

\subsection{Climate conditions during termination II and sea-level maximum}

Planktic foraminifera reappeared in the central Red Sea at about $130 \mathrm{ka} \mathrm{BP}$, which is about $2 \mathrm{ka}$ earlier than in the northern Red Sea (128 ka BP in KL23) (Fig. 3). At this time, sea level stood about $70 \mathrm{~m}$ lower than today (Fig. 3, 5a) and salinity must have dropped below 47 , the salinity tolerance limit of G. sacculifer (Hemleben et al., 1989). The complete recovery of the foraminiferal fauna in terms of abundance occurred at around $127-126 \mathrm{ka} \mathrm{BP}$, at similar sea level to the complete recovery during termination I (approximately 50$55 \mathrm{~m}$ below the present-day level) (Trommer et al., 2010), and is also characterised by a similar succession of species. This finding indicates a regular response of the Red Sea oceanography and planktic foraminifera community during terminations with similar rates of sea-level rises.

The dominance of G. sacculifer in KL9 after termination II, lasting approximately $\sim 5 \mathrm{ka}$, is similar to what was observed during termination I (overlapping samples in Fig. 7) 


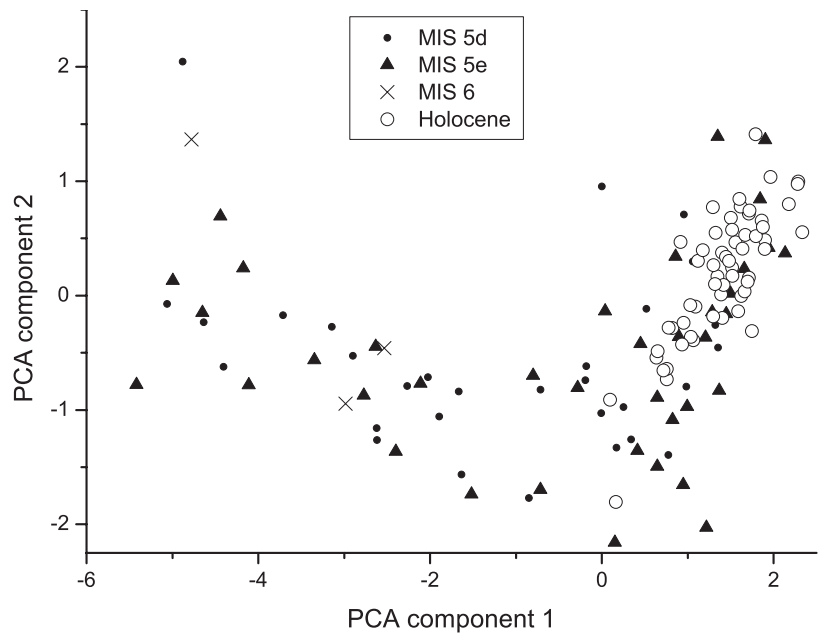

Fig. 7. Comparison of foraminiferal assemblages of MIS 6-5d and Holocene in core KL9 (most abundant species according to Siccha et al. (2009)). Plotted is PCA component 1 vs. PCA component 2. Overlapping areas display similar assemblages.

(Geiselhart, 1998; Schmelzer, 1998; Fenton et al., 2000; Trommer et al., 2010). For termination I, this has been interpreted as the result of oligotrophic conditions in the central Red Sea caused by strengthened summer circulation mode (Trommer et al., 2010), which was corroborated by modelling results (Biton et al., 2010). During termination II, G. sacculifer abundance changes appear to follow the summer insolation trend, in a similar manner as during the early Holocene (Fig. 8). The temporal coincidence of the changes in foraminiferal abundances during both insolation maxima points towards the same cause and effect mechanism acting during MIS 5e and the early Holocene period, with a dominating effect of the enhanced Indian SW Monsoon. Although KL11 lies in the central Red Sea, the foraminiferal faunas are rich in G. glutinata, as found today only in the southern Red Sea. We propose that this results from a strong summer circulation during a regime of enhanced Indian SW Monsoons (shaded area in Fig. 8). This would cause the KL11 site being affected by intruding nutrient-rich (intermediate-depth) waters from the south, causing chlorophyll- $a$ values that are more than twice as high as today (Fig. 5b). At the same time, KL9 site remained beyond the influence of the intruding waters, and thus its reconstructed chlorophyll- $a$ values remained comparable to present-day values (Fig. 5b). Such an intensified inflow of subsurface water into the Red Sea during MIS 5e could also explain the discrepancy between the oxygen isotope records of KL9 and KL11 and the resulting sea-level reconstruction (Fig. 5a). Whereas the annual mean sea surface temperature at the site of KL11 today is $0.5^{\circ} \mathrm{C}$ higher than at the site of KL9 (Conkright et al., 2001), a northward shift of the warm surface waters to KL9 and penetration of cooler waters from the south to KL11 would result in a lighter oxygen isotope ratio in planktic foraminiferal

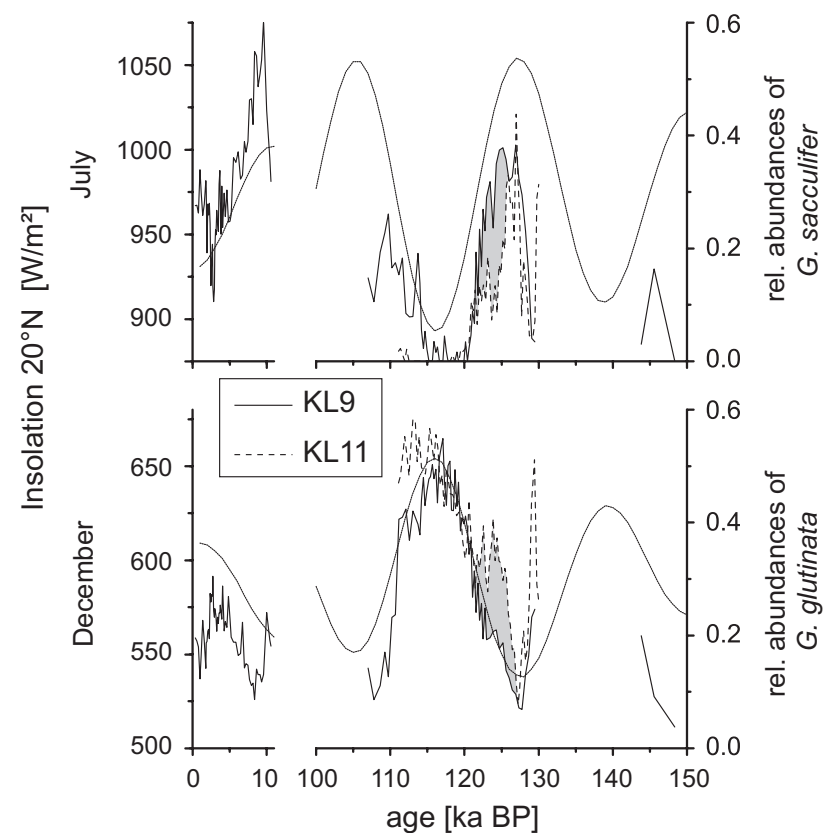

Fig. 8. Comparison of species abundances with insolation data $\left(20^{\circ} \mathrm{N}\right)$. Left: Holocene data only for KL9 (Trommer et al., 2010), right: this study including KL9 and KL11, above: July insolation and $G$. sacculifer abundances, below: December insolation and $G$. glutinata abundances. Grey shading indicates faunal offset during termination II, when KL11 was influenced by intruding intermediate waters during pronounced summer circulation.

tests in KL9, relative to KL11. A temperature difference of $+1^{\circ} \mathrm{C}$ (annual mean) at KL9, relative to KL11, would explain the $\sim 0.2 \%$ o difference in the oxygen isotope ratios between the cores (Fig. 2) and the sea-level reconstruction incongruity as indicated by Rohling et al. (2009).

$\mathrm{TEX}_{86}$ values for the northern Red Sea (KL23) during termination II reveal an SST increase of $\sim 3^{\circ} \mathrm{C}$ from 129 to $125 \mathrm{ka}$ (Figs. 6, 9). Since there is no contemporaneous shift of $\mathrm{TEX}_{86}$ with the co-registered BIT index, this increase cannot be attributed to an input of SOM. At present day, the northern Red Sea shows a pure endemic GDGT signal, but a strong northward advection of the open ocean GDGT signal during termination II might have reached the core location in the northern Red Sea and increased its $\mathrm{TEX}_{86}$. In this case, the central Red Sea core KL9 should show an even greater TEX $_{86}$ increase during the termination, since it should be even more affected, but which is not observed. Furthermore, as discussed in the previous paragraph, the central Red Sea KL9 seems to be located beyond the northward penetration of the intruding subsurface waters. Hypothetically, an increase of about $3{ }^{\circ} \mathrm{C}$ in the northern Red Sea record could also be explained by a shift of the growth season of the Crenarchaeota towards summer or by non-thermal factors such as salinity and nutrients. However, the membrane lipid distribution in the present day northern Red Sea correlates neither with 


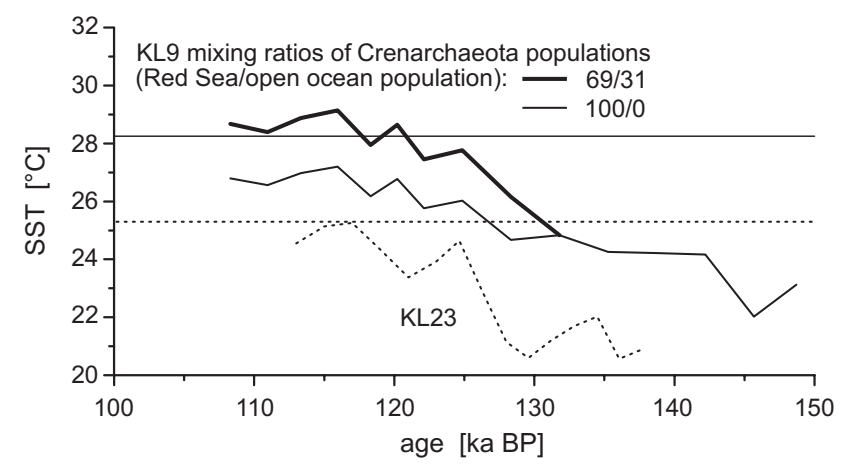

Fig. 9. TEX $_{86}$-based SST interpretations. KL23 SST record (dotted line, horizontal dotted $=$ modern SST at the core site) and KL9 SST signal interpreted as reflecting different mixing ratios of Red Sea versus open ocean Crenarchaeota population: $100 \%$ endemic Red Sea population (solid line) and after $130 \mathrm{ka}$ BP $69 \%$ endemic and $31 \%$ open ocean population (solid bold line, vertical solid line $=$ modern SST at the core site).

seasonal or deep water temperatures nor with salinity, nutrient concentrations, or diagenetic effects (Trommer et al., 2009). Additionally, our findings are consistent with estimates of SST increases during termination II of $2-3^{\circ} \mathrm{C}$ in the Arabian Sea using different proxies (Emeis et al., 1995; Rostek et al., 1997; Saher et al., 2009) and are similar to the magnitude of SST changes in tropical oceans across termination II (McCulloch and Esat, 2000; Kukla et al., 2002). The SST increase during the termination I in the northern Red Sea was reported as about $1^{\circ} \mathrm{C}$ (TEX 86 reconstruction, Trommer et al., 2010) or $2{ }^{\circ} \mathrm{C}\left(\mathrm{U}_{37}^{\mathrm{K}}\right.$ reconstruction, Arz et al., 2007). Therefore, it seems reasonable that SST has increased by $\sim 3^{\circ} \mathrm{C}$ in the northern Red Sea during termination II.

The $\mathrm{TEX}_{86}$ trend during termination II in central Red Sea core KL9 must be considered as a mixed signal between an endemic Red Sea GDGT signal and an advected open ocean signal. At present, the calibration of Trommer et al. (2009) suggests a contribution of about $72 \%$ of the endemic Red Sea Crenarchaeota population and $28 \%$ from the open-ocean population, at the site of KL9. The degree of admixture of the open ocean Crenarchaeota signal could be influenced by sea-level change, because this severely affects the water exchange between the Red Sea and the open ocean. At low sea level, such as during the time before the recovery of planktic foraminiferal faunas in termination II, exchange between the Red Sea and Gulf of Aden was severely restricted (Rohling and Zachariasse, 1996; Rohling et al., 1998; Siddall et al., 2003, 2004; Biton et al., 2008), such that enhanced water residence times caused salinities in the Red Sea in excess of 47. With such limited exchange, advection of significant amounts of open-ocean GDGTs into the Red Sea is unlikely. Assuming no exchange over the entire observed period, this would theoretically imply an SST increase of $4-4.5^{\circ} \mathrm{C}$ in total from MIS 6 to MIS 5e, with only $\sim{ }^{\circ} \mathrm{C}$ change during the actual termination (Fig. 9, 100/0). But as sea level rose, improved exchange caused salinity to drop below the 47 threshold, increasing the potential for advection (and maybe survival) of the open-ocean GDGT signal into the Red Sea. Accordingly, we assume that before $130 \mathrm{ka}$ BP the central Red Sea $\mathrm{TEX}_{86}$ signal derived exclusively from northern Red Sea Crenarchaeota (and hence $\mathrm{TEX}_{86}$ values reflect SST following the Trommer et al. (2009) calibration) (Fig. 9). Given that sea level rose towards higher levels than today during MIS 5e (Plaziat et al., 1995; McCulloch and Esat, 2000; Orszag-Sperber et al., 2001; Siddall et al., 2006; Rohling et al., 2008b; Kopp et al., 2009; Muhs et al., 2011), it is highly likely that after $130 \mathrm{ka}$ BP mixing between the two populations would have had taken place, so that the $\mathrm{TEX}_{86}$ values cannot be straightforwardly interpreted in terms of SST. Instead, they would represent a mixing product between the endemic Red Sea and open ocean populations.

Following Biton et al. (2010), we calculate the contributions of the different GDGT signals by assuming that the SST trend at KL9 was similar to that at KL23, with an approximate offset of $3{ }^{\circ} \mathrm{C}$, as found today. These calculations suggest that the Crenarchaeota population at the site of KL9 would consist of $69 \%$ northern Red Sea population and $31 \%$ of the open ocean population during MIS 5e (Fig. 9), which is, within the uncertainties, similar to the observed modern mixing relationship at that site (Biton et al., 2010). However, a mixing rate higher than $70 \%$ endemic and $30 \%$ open ocean contribution to $\mathrm{TEX}_{86}$ results in unrealisticly high reconstructed SSTs for this site after $117 \mathrm{ka}$ BP. The environmental conditions for the period after $117 \mathrm{ka} \mathrm{BP}$, that is a minimum in summer insolation (Fig. 8) and already lowered sea level (Figs. 5a, 6), oppose a mixing ratio with higher than $30 \%$ open ocean component by intrusion of Gulf of Aden intermediate water. Foraminifera data of our study indicate that this might have occurred at KL11 (and only before $\sim 120 \mathrm{ka}$ BP, Fig. 8) but not at KL9. Therefore, the GDGT mixing rates at KL9 must be considered as lying in between the relationships of 100/0 and 70/30 (Red Sea/open ocean population) in the investigated interglacial period, which is similar to Holocene results (Biton et al., 2010).

Unlike at termination I, there is no sapropel-like (anoxic sediment) layer at or after termination II in the investigated cores. Since rates of sea-level rise were roughly similar during termination II and termination I (Siddall et al., 2003, 2006; Rohling et al., 2008b), other processes need to be inferred to explain the lack of a termination II sapropel. Arid climate conditions and water mass cooling through high evaporation rates promote deep water formation today in the Gulf of Suez and Aqaba (Eshel et al., 1994; Eshel and Naik, 1997; Manasrah et al., 2004). Therefore, increased or at least continuous exchange between the Gulf of Aqaba and the northern Red Sea may have led to a continuous ventilation of the deep water and surface sediments. In addition to very arid climate conditions during termination II (BarMatthews et al., 2003; Fleitmann et al., 2003), we propose 
that the mid-termination drop in sea level (Esat, 1999; Siddall et al., 2006; Thomas et al., 2009) may have caused intermittently sufficient higher salinity in the Red Sea, improving ventilation and preventing the build-up of anoxic conditions during termination II.

After termination II, we observe an increase in the BIT index in both cores that culminates between 122 and $120 \mathrm{ka} \mathrm{BP}$, $1.5-3 \mathrm{ka}$ after the sea-level highstand. Holocene sediments in the central Red Sea as well as recent subsurface sediments throughout the Red Sea show BIT indices on average lower than 0.1 (Trommer et al., 2009, 2010). The elevated BIT index observed contemporaneously in two cores suggests a relative increase in the input of SOM (Hopmans et al., 2004; Weijers et al., 2006; Kim et al., 2006; Walsh et al., 2008) into the Red Sea, for which several explanations must be considered. A first potential mechanism for delivering soil material into the Red Sea would be through flooding of the basin's wide shelf areas during sea-level rise, but this does not agree with the timing of the BIT increase several millennia after the actual sea-level rise (Fig. 6). A second potential explanation might be that the higher BIT values resulted from decreased levels of crenarchaeol and thus Crenarchaeota productivity (cf. Castañeda et al., 2010). But given that chlorophyll- $a$ reconstructions suggest higher productivity during this period, and that the TEX 86 index (which considers the Crenarchaeol isomer) shows no consistent change, the increase of BIT as an indication of a decrease in Crenarchaeota productivity is not supportable.

The most likely explanations for the increase in the BIT index must therefore include enhanced river-discharge of SOM. There is a plausible river system that drains the Baraka (Tokar) catchment in Sudan (Fig. 1), which today is active 40-70 days per year (mainly during autumn), discharging between 200 and $970 \times 10^{6} \mathrm{~m}^{3}$ water at $18.5^{\circ} \mathrm{N}$ into the Red Sea (Whiteman, 1971). As a possible third mechanism, it could be expected that this increased discharge of SOM into the Red Sea occured with the onset of increased precipitation around the Red Sea region (Bar-Matthews et al., 2003; Fleitmann et al., 2003). Yet due to the arid conditions during MIS 6 , as indicated by aeolian dust peaks (Rohling et al., 2008a), no soils would have been available by this time to be washed out. However, also the timing of the BIT increase does not coincide with the precipitation onset in MIS 5e during termination II .

The fourth and most likely argumentation for the observed increase in the BIT index involves the development of vegetation cover in the Red Sea region. Records from the Red Sea Mountains in Egypt show vegetation depositions from a wet period of local significance (Moeyersons et al., 2002), and speleothem records around the Red Sea show increasing rainfalls/humidity with the beginning of MIS 5e in Oman (Fleitmann et al., 2003) and from 124-119 ka BP in Israel (BarMatthews et al., 2003). This period of enhanced zonal precipitation (Herold and Lohmann, 2009) was coincident with a period of strong insolation-forced African Monsoons that caused intense sapropel formation in the eastern Mediterranean (Rossignol-Strick, 1983; Rohling et al., 2002; van der Meer et al., 2007; Osborne et al., 2008). Our BIT data therefore indicate that during this humid period the vegetation cover could develop and substantial amounts of soil formed in the Red Sea region. Consequently, as aridity increased and vegetation weakened after $\sim 122-120 \mathrm{ka} B \mathrm{BP}$, seasonally still significant rainfalls were able to wash out SOM into the Red Sea and caused these elevated BIT values. Although SOM import from such a system could be locally measurable, it has to be emphasised that the system's modern freshwater flux is equivalent to at most $2 \mathrm{~mm}$ of sea level when distributed over the entire Red Sea. Even with a hypothetical 100 -fold increase in its flux during MIS 5e, the total freshwater flux would remain a negligible term in the overall Red Sea freshwater budget, and hence in the Red Sea sea-level method.

\subsection{Oceanography of MIS 5 after the sea-level maximum}

After the sea-level maximum and with rising BIT, G. glutinata starts to dominate the assemblage at the KL9 core position for over $10 \mathrm{ka}$. This differs from the faunal assemblage changes at this site during the Holocene and the present (Figs. 4,7 ) and likely reflects a different oceanographic situation. The observed dominance of G. glutinata in the central Red Sea (see also Fenton, 1998) is unique, since highest G. glutinata abundances in the Red Sea are today observed only in the very south (Auras-Schudnagies et al., 1989; Siccha et al., 2009). G. glutinata occurs in general in productive regions (Cullen and Prell, 1984; Naidu and Malmgren, 1996; Schulz et al., 2002; Storz et al., 2009), suggesting that the cause of this increase is indeed linked to productivity, as indicated by our transfer function results, although absolute values have to be taken with care due to non-analogue conditions (Fig. 5). Concomitant with the G. glutinata trend in the central Red Sea, a G. ruber maximum occurs in the record of KL23 (Fig. 3), which points to a significant change in the circulation system affecting the Red Sea far north.

The timing of the G. glutinata increase in KL11 could be viewed as an expression of increased nutrient advection from the Gulf of Aden into the Red Sea due to high sea level and strong SW Monsoon circulation. But this scenario does not explain the further rise of G. glutinata abundances, as also seen in KL9, following the winter insolation increase (Fig. 8) when sea level was falling (Rohling et al., 2008b) and the SW Monsoon was weakening (Fleitmann et al., 2003). After $120 \mathrm{ka}$ BP, productivity reconstructions for KL9 and KL11 reach similar levels (Fig. 5b) and oxygen isotope ratios are also similar (Fig. 5a), which suggests that the foraminifera lived in same water masses at the core positions. Modern observations show that winter is the more productive season in the central to northern Red Sea (Veldhuis et al., 1997). 
Consequently, the observed productivity increase may suggest more pronounced winter conditions, which followed the period of enhanced Indian SW Monsoon circulation.

Strong SW Monsoons were obviously limited to peak interglacial MIS 5e (Burns et al., 1998, 2001; Fleitmann et al., 2003) before sea-level regression heralded more glacial conditions (Anklin et al., 1993) and the NE Monsoon became enhanced (Rostek et al., 1997). At the same time as our $G$. glutinata peak, Reichart et al. (1997) report dry glacial-like conditions from Murray Ridge in the Arabian Sea, and there is evidence for increased NE winter monsoonal winds over the Arabian Sea (Montoya et al., 2000), which are held responsible for a productivity maximum (Rostek et al., 1997; Ivanova et al., 2003). Benthic foraminiferal faunas from the Red Sea (Badawi et al., 2005) and the Gulf of Aden (AlmogiLabin et al., 2000) also suggest a short productivity peak under enhanced NE Monsoon conditions. The sensitivity of Red Sea circulation to atmospheric forcing is perhaps best demonstrated by the fact that the relative abundance changes of G. glutinata not only follow the changes in winter insolation, but even reflect the higher amplitude of the insolation changes during MIS 5 relative to those during the Holocene (Fig. 8).

\section{Conclusions}

The investigation of termination II and interglacial stages MIS 5e-d in the Red Sea with newly developed multi-proxy data reveals similarities to termination I and the Holocene. During both terminations, the planktic foraminiferal faunas recovered from glacial aplanktonic conditions at similar rates and with a similar sensitivity to sea level, following the same species succession (with G. sacculifer as the leading species). We find that higher sea level during MIS 5e alone had no superior effect on the Red Sea circulation, which was instead controlled by the insolation-driven intense Indian SW Monsoon. Changes in the abundance of G. sacculifer closely followed the summer insolation pattern. The abundance of this species reflects oligotrophic summer conditions during a strong prevailing SW monsoon, which is reflected in low chlorophyll- $a$ reconstructions for the central Red Sea. A subsequent productivity maximum is reconstructed between 122 and $112 \mathrm{ka}$ BP, based on high abundances of especially $G$. glutinata. This is interpreted in terms of more pronounced winter circulation at a time when the climate conditions became characterized by an intensification of the NE monsoon.

Our GDGT results suggest that the application of the TEX $_{86}$ on glacial-interglacial timescales in the Red Sea gives reasonable SST estimates in the northern Red Sea with the newly developed Red Sea calibration. SST in the northern Red Sea is found to have increased from $21^{\circ} \mathrm{C}$ during the glacial to $25^{\circ} \mathrm{C}$ during MIS $5 \mathrm{~d}$. Our interpretation of the TEX $_{86}$ record for the central Red Sea (only KL9) suggests that the mixing ratio between endemic and open-ocean Cre- narchaeota was about 70:30 during the Last Interglacial (MIS 5e), which is similar to that reconstructed for the present. Around $\sim 120 \mathrm{ka} \mathrm{BP}$, we find relatively enhanced amounts of soil-derived organic matter input, which likely reflect the impact of soil out-wash due to seasonal runoff events in a period of generally increasing aridity and reducing vegetation.

Acknowledgements. This project contributes to the German Science Foundation project DFG KU 2259/3-1 "RedSTAR" and UK Natural Environment Research Council Projects NE/H004424/1 and NE/E01531X/1. Gabriele Trommer received financial support by the Departmental Council of Finistère, France. Marcel van der Meer was funded by a Dutch Organization for Scientific Research (NWO) VIDI grant and Stefan Schouten by a NWO VICI grant. Sofie Jehle (University of Tübingen) is thanked for help with the micropaleontological sample preparation. Anchelique Mets (NIOZ) is thanked for help with the organic geochemical measurements. We are thankful to crew and cruise leader of RV Meteor $5 / 2$. We acknowledge helpful comments by two anonymous referees.

Edited by: G. M. Ganssen

\section{References}

Almogi-Labin, A., Hemleben, C., Meischner, D., and Erlenkeuser, H.: Paleoenvironmental events during the last 13,000 years in the central Red Sea as recorded by pteropoda, Paleoceanography, 6 , 83-98, 1991.

Almogi-Labin, A., Schmiedl, G., Hemleben, C., Siman-Tov, R., Segl, M., and Meischner, D.: The influence of the NE winter monsoon on productivity changes in the Gulf of Aden, NW Arabian Sea, during the last $530 \mathrm{ka}$ as recorded by foraminifera, Mar. Micropaleontol., 40, 295-319, 2000.

Anklin, M., Barnola, J. M., Beer, J., Blunier, T., Chappellaz, J., Clausen, H. B., Dahljensen, D., Dansgaard, W., Deangelis, M., Delmas, R. J., Duval, P., Fratta, M., Fuchs, A., Fuhrer, K., Gundestrup, N., Hammer, C., Iversen, P., Johnsen, S., Jouzel, J., Kipfstuhl, J., Legrand, M., Lorius, C., Maggi, V., Miller, H., Moore, J. C., Oeschger, H., Orombelli, G., Peel, D. A., Raisbeck, G., Raynaud, D., Schotthvidberg, C., Schwander, J., Shoji, H., Souchez, R., Stauffer, B., Steffensen, J. P., Stievenard, M., Sveinbjornsdottir, A., Thorsteinsson, T., and Wolff, E. W.: Climate instability during the last interglacial period recorded in the GRIP ice core, Nature, 364, 203-207, 1993.

Arz, H. W., Lamy, F., Ganopolski, A., Nowaczyk, N., and Pätzold, J.: Dominant Northern Hemisphere climate control over millennial-scale glacial sea-level variability, Quaternary Sci. Rev., 26, 312-321, 2007.

Auras-Schudnagies, A., Kroon, D., Ganssen, G., Hemleben, C., and Van Hinte, J. E.: Distributional pattern of planktonic foraminifers and pteropods in surface waters and top core sediments of the Red Sea, and adjacent areas controlled by the monsoonal regime and other ecological factors, Deep-Sea Res., 36, 1515-1533, 1989.

Badawi, A., Schmiedl, G., and Hemleben, C.: Impact of late Quaternary environmental changes on deep-sea benthic foraminiferal faunas of the Red Sea, Mar. Micropaleontol., 58, 13-30, 2005. 
Bar-Matthews, M., Ayalon, A., Gilmour, M., Matthews, A. and Hawkesworth, C.: Sea-land oxygen isotopic relationships from planktonic foraminifera and speleothems in the Eastern Mediterranean region and their implication for paleorainfall during interglacial intervals, Geochim. Cosmochim. Ac., 67, 3181-3199, 2003.

Biton, E., Gildor, H., and Peltier, W. R.: Red Sea during the Last Glacial Maximum: Implications for sea level reconstruction, Paleoceanography, 23, PA1214, doi:10.1029/2007PA001431, 2008.

Biton, E., Gildor, H., Trommer, G., Siccha, M., Kucera, M., van der Meer, M. T. J., and Schouten, S.: Sensitivity of Red Sea circulation to monsoonal variability during the Holocene: An integrated data and modeling study, Paleoceanography, 25, PA4209, doi:10.1029/2009PA001876, 2010.

Burns, S. J., Matter, A., Frank, N., and Mangini, A.: Speleothembased paleoclimate record from northern Oman, Geology, 26, 499-502, 1998.

Burns, S. J., Fleitmann, D., Matter, A., Neff, U., and Mangini, A.: Speleothem evidence from Oman for continental pluvial events during interglacial periods, Geology, 29, 623-626, 2001.

Castañeda, I. S., Schefuss, E., Pätzold, J., Sinninghe Damsté, J. S., Weldeab, S., and Schouten, S.: Millennial-scale sea surface temperature changes in the eastern Mediterranean (Nile River Delta region) over the last 27,000 years, Paleoceanography, 25, PA1208, doi:10.1029/2009PA001740, 2010.

Cember, R. P.: On the sources, formation and circulation of Red Sea Deep Water, J. Geophys. Res., 93, 8175-8191, 1988.

Chen, F. H., Qiang, M. R., Zeng, Z. D., Wang, H. B., and Bloemendal, J.: Stable East Asian monsoon climate during the Last Interglacial (Eemian) indicated by paleosol S1 in the western part of the Chinese Loess Plateau, Global Planet. Change, 36, 171-179, 2003.

Clemens, S., Prell, W., Murray, D., Shimmield, G., and Weedon, G.: Forcing mechanisms of the Indian Ocean monsoon, Nature, 353, 720-725, 1991.

Conkright, M. E., Locarnini, R. A., Garcia, H. E., O’Brian, T. D., Boyer, T. P., Stephens, C., and Antonov, J. I.: World Ocean Atlas 2001, http://odv.awi.de/en/data/ocean/world_ocean_atlas_2001/, 2001.

Cuffey, K. M. and Marshall, S. J.: Substantial contribution to sealevel rise during the last interglacial from the Greenland ice sheet, Nature, 404, 591-594, 2000.

Cullen, J. L. and Prell, W. L.: Planktonic foraminifera of the northern Indian Ocean: distribution and preservation in surface sediments, Mar. Micropaleontol., 9, 1-52, 1984.

Emeis, K. C., Anderson, D. M., Doose, H., Kroon, D., and SchulzBull, D.: Sea-Surface Temperatures and the History of Monsoon Upwelling in the Northwest Arabian Sea during the Last 500,000 Years, Quaternary Res., 43, 355-361, 1995.

Esat, T. M., McCulloch, M. T., Chappell, J., Pillans, B., and Omura, A.: Rapid fluctuations in sea level recorded at Huon Peninsula during the penultimate deglaciation, Science, 283, 197-201, 1999.

Eshel, G. and Naik, N. H.: Climatological Coastal Jet Collision, Intermediate Water Formation, and the General Circulation of the Red Sea, American Meteorological Society, 27, 1233-1257, 1997.

Eshel, G., Cane, M. A., and Blumenthal, M. B.: Modes of sub- surface, intermediate, and deep water renewal in the Red Sea, J. Geophys. Res., 99, 15941-15952, 1994.

Fenton, M.: Late quaternary history of Red Sea outflow, Ph. D. Thesis, School of Ocean and Earth Science, Southampton University, Southampton, 226 pp., 1998.

Fenton, M., Geiselhart, S., Rohling, E., and Hemleben, C.: Aplanktonic zones in the Red Sea, Mar. Micropaleontol., 40, 277-294, 2000.

Fleitmann, D., Burns, S. J., Neff, U., Mangini, A., and Matter, A.: Changing moisture sources over the last 330,000 years in Northern Oman from fluid-inclusion evidence in speleothems, Quaternary Res., 60, 223-232, 2003.

Fuhrman, J. A., McCallum, K., and Davis, A.: Novel major archaebacterial group from marine plankton, Nature, 356, 148-149, 1992.

Geiselhart, S.: Late Quaternary paleoceanographic and paleoclimatologic history of the Red Sea during the last 380.000 years: Evidence from stable isotopes and faunal assemblages, Tübinger Mikropaläontologische Mitteilungen, 17, 1-87, 1998.

Gersonde, R., Crosta, X., Abelmann, A., and Armand, L.: Seasurface temperature and sea ice distribution of the Southern Ocean at the EPILOG Last Glacial Maximum - A circumAntarctic view based on siliceous microfossil records, Quaternary Sci. Rev., 24, 869-896, 2005.

Hemleben, C., Meischner, D., Zahn, R., Almogi-Labin, A., Erlenkeuser, H., and Hiller, B.: Three hundred eighty thousand year long stable isotope and faunal records from the Red Sea: Influence of global sea level change on hydrography, Paleoceanography, 11, 147-156, 1996.

Hemleben, C., Spindler, M., and Anderson, O.: Modern Planktonic Foraminifera, Springer-Verlag, New York, 363 pp., 1989.

Henderson, G. M. and Slowey, N. C.: Evidence from U-Th dating against Northern Hemisphere forcing of the penultimate deglaciation, Nature, 404, 61-66, 2000.

Herndl, G. J., Reinthaler, T., Teira, E., van Aken, H., Veth, C., Pernthaler, A., and Pernthaler, J.: Contribution of Archaea to total prokaryotic production in the deep Atlantic Ocean, Appl. Environ. Microb., 71, 2303-2309, 2005.

Herold, M. and Lohmann, G.: Eemian tropical and subtropical African moisture transport: an isotope modelling study, Clim. Dyn., 33, 1075-1088, doi:10.1007/s00382-008-0515-2, 2009.

Hoefs, M. J., Schouten, S., de Leeuw, J. W., King, L. L., Wakeham, S. G., and Sinninghe Damsté, J. S.: Ether Lipids of Planktonic Archaea in the Marine Water Column, Appl. Environ. Microb., 63, 3090-3095, 1997.

Hoogakker, B. A. A., Klinkhammer, G. P., Elderfield, H., Rohling, E. J., and Hayward, C.: Mg/Ca paleothermometry in high salinity environments, Earth Planet. Sc. Lett., 284, 583-589, 2009.

Hopmans, E. C., Schouten, S., Pancost, R. D., van der Meer, M. T. J., and Sinninghe Damsté, J. S.: Analysis of intact tetraether lipids in archaeal cell material and sediments by high performance liquid chromatography/atmospheric pressure chemical ionization mass spectrometry, Rapid Communications in Mass Spectrometry, 14, 585-589, 2000.

Hopmans, E. C., Weijers, J. W. H., Schefuss, E., Herfort, L., Sinninghe Damsté, J. S., and Schouten, S.: A novel proxy for terrestrial organic matter in sediments based on branched and isoprenoid tetraether lipids, Earth Planet. Sc. Lett., 224, 107-116, 2004. 
Imbrie, J., Hayes, J., Martinson, D., McIntyre, A., Mix, A., Morley, J., Pisias, N., Prell, W., Shackleton, N., and Berger, A.: The orbital theory of Pleistocene climate: support from a revised chronology of the marine $\delta^{18} \mathrm{O}$ record, in: Milankovitch and Climate, Understanding the Response to Orbital Forcing, Part 1, edited by: Berger, A., Imbrie, J., Hays, J., Kukla, G., and Saltzman, B., D. Reidel Publishing Company, Norwell, Massachusetts, 269-305, 1984.

Ivanova, E., Schiebel, R., Singh, A. D., Schmiedl, G., Niebler, H. S., and Hemleben, C.: Primary production in the Arabian Sea during the last 135000 years, Palaeogeogr. Palaeocl., 197, 6182, 2003.

Jouzel, J., Masson-Delmotte, V., Cattani, O., Dreyfus, G., Falourd, S., Hoffmann, G., Minster, B., Nouet, J., Barnola, J. M., Chappellaz, J., Fischer, H., Gallet, J. C., Johnsen, S., Leuenberger, M., Loulergue, L., Luethi, D., Oerter, H., Parrenin, F., Raisbeck, G., Raynaud, D., Schilt, A., Schwander, J., Selmo, E., Souchez, R., Spahni, R., Stauffer, B., Steffensen, J. P., Stenni, B., Stocker, T. F., Tison, J. L., Werner, M., and Wolff, E. W.: Orbital and millennial Antarctic climate variability over the past 800,000 years, Science, 317, 793-796, 2007.

Juggins, S.: C2 Data Analysis, 2003.

Kim, J. H., Schouten, S., Buscail, R., Ludwig, W., Bonnin, J., Sinninghe Damsté, J. S., and Bourrin, F.: Origin and distribution of terrestrial organic matter in the NW Mediterranean (Gulf of Lions): Exploring the newly developed BIT index, Geochem. Geophy. Geosy., 7, Q11017, doi:10.1029/2006GC001306, 2006.

Kim, J., Schouten, S., Hopmans, E. C., Donner, B., and Sinninghe Damsté, J. S.: Global sediment core-top calibration of the TEX 86 paleothermometer in the ocean, Geochim. Cosmochim. Ac., 72, 1154-1173, 2008.

Kim, J. H., Zarzycka, B., Buscail, R., Peterse, F., Bonnin, J., Ludwig, W., Schouten, S., and Sinninghe Damsté, J. S.: Contribution of river-borne soil organic carbon to the Gulf of Lions (NW Mediterranean), Limnol. Oceanogr., 55, 507-518, 2010.

Kopp, R. E., Simons, F. J., Mitrovica, J. X., Maloof, A. C., and Oppenheimer, M.: Probabilistic assessment of sea level during the last interglacial stage, Nature, 462, 863-867, doi:10.1038/nature08686, 2009.

Kukla, G., Bender, M., de Beaulieu, J., Bond, G., Broecker, W., Cleveringa, P., Gavin, J., Herbert, T., Imbrie, J., Jouzel, J., Keigwin, L. D., Knudsen, K.-L., McManus, J. F., Merkt, J., Muhs, D. R., Müller, H., Poore, R. Z., Porter, S. C., Seret, G., Shackleton, N. J., Turner, C., Tzedakis, P. C., and Winograd, I. J.: Last Interglacial Climates, Quaternary Res., 58, 2-13, 2002.

Lambeck, K. and Chappell, J.: Sea level change through the last glacial cycle, Science, 292, 679-686, 2001.

Legge, H. L., Mutterlose, J., and Arz, H. W.: Climatic changes in the northern Red Sea during the last 22,000 years as recorded by calcareous nannofossils, Paleoceanography, 21, PA1003, doi:10.1029/2005PA001142, 2006.

Lisiecki, L. E. and Raymo, M. E.: A Pliocene-Pleistocene stack of 57 globally distributed benthic $\delta^{18} \mathrm{O}$ records, Paleoceanography, 20, PA1003, doi:10.1029/2004PA001071, 2005.

Locke, S. and Thunell, R.: Paleoceanographic record of the last glacial/interglacial cycle in the Red Sea and Gulf of Aden, Palaeogeogr. Palaeocl., 64, 163-187, 1988.

Manasrah, R., Badran, M., Lass, H. U., and Fennel, W.: Circulation and winter deep-water formation in the northern Red Sea,
Oceanologia, 46, 5-23, 2004.

McCulloch, M. and Esat, T.: The coral record of last interglacial sea levels and sea surface temperatures, Chem. Geol., 169, 107-129, 2000.

Moeyersons, J., Vermeersch, P. M., and Van Peer, P.: Dry cave deposits and their palaeoenvironmental significance during the last 115 ka, Sodmein Cave, Red Sea Mountains, Egypt, Quaternary Sci. Rev., 21, 837-851, 2002.

Montoya, M., von Storch, H. and Crowley, T. J.: Climate simulation for $125 \mathrm{kyr}$ BP with a coupled ocean-atmosphere general circulation model, J. Climate, 13, 1057-1072, 2000.

Muhs, D. R., Simmons, K. R., Schumann, R. R., and Halley, R. B.: Sea-level history of the past two interglacial periods: new evidence from U-series dating of reef corals from south Florida, Quaternary Sci. Rev., 30, 570-590, doi:10.1016/j.quascirev.2010.12.019, 2011.

Naidu, P. D. and Malmgren, B. A.: A high-resolution record of late quaternary upwelling along the Oman Margin, Arabian Sea based on planktonic foraminifera, Paleoceanography, 11, 129140, 1996.

Orszag-Sperber, F., Plaziat, J., Baltzer, F., and Purser, B.: Gypsum salina-coral reef relationships during the Last Interglacial (Marine Isotopic Stage 5e) on the Egyptian Red Sea coast: a Quaternary analogue for Neogene marginal evaporites?, Sediment. Geol., 140, 61-85, 2001.

Osborne, A. H., Vance, D., Rohling, E. J., Barton, N., Rogerson, M., and Fello, N.: A humid corridor across the Sahara for the migration of early modern humans out of Africa 120,000 years ago, P. Natl. Acad. Sci. U.S.A., 105, 16444-16447, 2008.

Otto-Bliesner, B. L., Marsha, S. J., Overpeck, J. T., Miller, G. H., and $\mathrm{Hu}, \mathrm{A}$. X.: Simulating arctic climate warmth and icefield retreat in the last interglaciation, Science, 311, 1751-1753, 2006.

Overpeck, J. T., Webb, T., and Prentice, I. C.: Quantitative interpretation of fossil pollen spectra: dissimilarity coefficients and the method of modern analogs, Quaternary Res., 23, 87-108, 1985.

Patzert, W. C.: Wind-induced reversal in Red Sea circulation, DeepSea Res., 21, 109-121, 1974.

Plaziat, J. C., Baltzer, F., Choukri, A., Conchon, O., Freytet, P., Orszag-Sperber, F., Purser, B., Raguideau, A., and Reyss, J. L.: Quaternary changes in the Egyptian shoreline of the northwestern Red Sea and Gulf of Suez, Quatern. Int., 30, 11-22, 1995.

Reichart, G. J., den Dulk, M., Visser, H. J., van der Weijden, C. H., and Zachariasse, W. J.: A $225 \mathrm{kyr}$ record of dust supply, paleoproductivity and the oxygen minimum zone from the Murray Ridge (northern Arabian Sea), Palaeogeogr. Palaeocl., 134, 149169, 1997.

Rohling, E. J. and Zachariasse, W. J.: Red Sea outflow during the last glacial maximum, Quatern. Int., 31, 77-83, 1996.

Rohling, E. J., Fenton, M., Jorissen, F. J., Bertrand, P., Ganssen, G., and Caulet, J. P.: Magnitudes of sea-level lowstands of the past 500,000 years, Nature, 394, 162-165, 1998.

Rohling, E. J., Cane, T. R., Cooke, S., Sprovieri, M., Bouloubassi, I., Emeis, K. C., Schiebel, R., Kroon, D., Jorissen, F. J., Lorre, A., and Kemp, A. E. S.: African monsoon variability during the previous interglacial maximum, Earth Planet. Sc. Lett., 202, 6175, 2002.

Rohling, E. J., Sprovieri, M., Cane, T., Casford, J. S. L., Cooke, S., Bouloubassi, I., Emeis, K. C., Schiebel, R., Rogerson, M., and Hayes, A.: Reconstructing past planktic foraminiferal habi- 
tats using stable isotope data: a case history for Mediterranean sapropel S5, Mar. Micropaleontol., 50, 89-123, 2004.

Rohling, E. J., Grant, K., Hemleben, C., Kucera, M., Roberts, A. P., Schmeltzer, I., Schulz, H., Siccha, M., Siddall, M., and Trommer, G.: New constraints on the timing of sea level fluctuations during early to middle marine isotope stage 3, Paleoceanography, 23, PA3219, doi:10.1029/2008PA001617, 2008a.

Rohling, E. J., Grant, K., Hemleben, C., Siddall, M., Hoogakker, B. A. A., Bolshaw, M., and Kucera, M.: High rates of sea-level rise during the last interglacial period, Nat. Geosci., 1, 38-42, $2008 \mathrm{~b}$.

Rohling, E. J., Grant, K., Bolshaw, M., Roberts, A. P., Siddall, M., Hemleben, C., and Kucera, M.: Antarctic temperature and global sea level closely coupled over the past five glacial cycles, Nat. Geosci., 2, 500-504, 2009.

Rossignol-Strick, M.: African monsoons, and immediate climate response to orbital insolation, Nature, 304, 46-49, 1983.

Rostek, F., Bard, E., Beaufort, L., Sonzogni, C., and Ganssen, G.: Sea surface temperature and productivity records for the past 240 kyr in the Arabian Sea, Deep-Sea Res. Pt. II, 44, 1461-1480, 1997.

Saher, M., Rostek, F., Jung, S. J. A., Bard, E., Schneider, R., Greaves, M., Ganssen, G., Elderfield, H., and Kroon, D.: Western Arabian Sea SST during the penultimate interglacial: A comparison of $\mathrm{U}_{37}^{K^{\prime}}$ and $\mathrm{Mg} / \mathrm{Ca}$ paleothermometry, Paleoceanography, 24, PA2212, doi:10.1029/2007PA001557, 2009.

Schmelzer, I.: High-frequency event-stratigraphy and paleoceanography of the Red Sea, Ph. D. Thesis, Institute of Geosciences, University of Tübingen, Tübingen, 124 pp., 1998.

Schouten, S., Hopmans, E. C., Pancost, R. D., and Sinninghe Damsté, J. S.: Widespread occurrence of structurally diverse tetraether membrane lipids: Evidence for the ubiquitous presence of low-temperature relatives of hyperthermophiles, P. Natl Acad. Sci. U.S.A., 97, 14421-14426, 2000.

Schouten, S., Hopmans, E. C., Schefuss, E., and Sinninghe Damsté, J. S.: Distributional variations in marine crenarchaeotal membrane lipids: a new tool for reconstructing ancient sea water temperatures?, Earth Planet. Sc. Lett., 204, 265-274, 2002.

Schouten, S., Huguet, C., Hopmans, E. C., Kienhuis, M. V. M., and Sinninghe Damsté, J. S.: Analytical Methodology for TEX 86 paleothermometry by high-performance liquid chromatography/atmospheric pressure chemical ionization-mass spectrometry, Anal. Chem., 79, 2940-2944, 2007.

Schulz, H., von Rad, U., Ittekkot, V., Clift, P. D., Kroon, D., Gaedicke, C., and Craig, J.: Planktic foraminifera, particle flux and oceanic productivity off Pakistan, NE Arabian Sea: modern analogues and application to the paleoclimatic record, in: The Tectonic and Climatic Evolution of the Arabian Sea Region, No. 195, Geological Society Special Publications, London, 499-516, 2002.

Shackleton, N. J., Sanchez-Goni, M. F., Pailler, D., and Lancelot, Y.: Marine Isotope Substage 5e and the Eemian interglacial, Global Planet. Change, 36, 151-155, 2003.

Siccha, M.: Planktonic foraminifera transfer function approach to Red Sea paleoceanography, Ph. D. Thesis, Institute of Geosciences, University of Tübingen, Tübingen, 144 pp., 2009.

Siccha, M., Trommer, G., Schulz, H., Hemleben, C., and Kucera, M.: Factors controlling the distribution of planktonic foraminifera in the Red Sea and implications for the development of transfer functions, Mar. Micropaleontol., 72, 146-156,
2009.

Siddall, M., Rohling, E., Almogi-Labin, A., Hemleben, C., Meischner, D., Schmelzer, I., and Smeed, D.: Sea-level fluctuations during the last glacial cycle, Nature, 423, 853-858, 2003.

Siddall, M., Smeed, D., Hemleben, C., Rohling, E. J., Schmelzer, I., and Peltier, W.: Understanding the Red Sea response to sea level, Earth Planet. Sc. Lett., 225, 421-434, 2004.

Siddall, M., Bard, E., Rohling, E. J., and Hemleben, C.: Sea-level reversal during Termination II, Geology, 34, 817-820, 2006.

Sinninghe Damsté, J. S., Rijpstra, W. I. C., Hopmans, E. C., Prahl, F. G., Wakeham, S. G., and Schouten, S.: Distribution of membrane lipids of planktonic Crenarchaeota in the Arabian Sea, Appl. Environ. Microb., 68, 2997-3002, 2002.

Smeed, D.: Seasonal variation of the flow in the strait of Bab al Mandab, Oceanol. Acta, 20, 773-781, 1997.

Smeed, D.: Exchange through the Bab el Mandab, Deep-Sea Res. Pt. II, 51, 455-474, 2004.

Sofianos, S. and Johns, W.: An Oceanic General Circulation Model (OGCM) investigation of the Red Sea circulation: 1. Exchange between the Red Sea and the Indian Ocean, J. Geophys. Res., 107, 3196, doi:10.1029/2001JC001184, 2002.

Sofianos, S. and Johns, W.: An Oceanic General Circulation Model (OGCM) investigation of the Red Sea circulation: 2. Threedimensional circulation in the Red Sea, J. Geophys. Res., 108, 3066, doi:10.1029/2001JC001185, 2003.

Sofianos, S., Johns, W., and Murray, S.: Heat and freshwater budgets in the Red Sea from direct observations at Bab el Mandeb, Deep-Sea Res. Pt. II, 49, 1323-1340, 2002.

Souvermezoglou, E., Metzl, N., and Poisson, A.: Red Sea budgets of salinity, nutrients and carbon calculated in the Strait of BabEl-Mandab during the summer and winter seasons, J. Mar. Res., 47, 441-456, 1989.

Storz, D., Schulz, H., Waniek, J. J., Schulz-Bull, D. E., and Kucera, M.: Seasonal and interannual variability of the planktic foraminiferal flux in the vicinity of the Azores Current, Deep-Sea Res. Pt. I, 56, 107-124, 2009.

Thomas, A. L., Henderson, G. M., Deschamps, P., Yokoyama, Y., Mason, A. J., Bard, E., Hamelin, B., Durand, N., and Camoin, G.: Penultimate Deglacial Sea-Level Timing from Uranium/Thorium Dating of Tahitian Corals, Science, 324, 11861189, 2009.

Thompson, P. R., Be, A. W. H., Duplessy, J. C., and Shackleton, N. J.: Disappearance of pink-pigmented Globigerinoides ruber at 120,000 yr BP in the Indian and Pacific Oceans, Nature, 280, 554-558, 1979.

Thompson, W. G. and Goldstein, S. L.: Open-system coral ages reveal persistent suborbital sea-level cycles, Science, 308, 401404, 2005.

Thunell, R. C., Locke, S., and Williams, D. F.: Glacio-eustatic sealevel control on Red Sea salinity, Nature, 334, 601-604, 1988.

Trommer, G., Siccha, M., van der Meer, M. T. J., Schouten, S., Sinninghe Damsté, J. S., Schulz, H., Hemleben, C., and Kucera, M.: Distribution of Crenarchaeota tetraether membrane lipids in surface sediments from the Red Sea, Org. Geochem., 40, 724 731, 2009.

Trommer, G., Siccha, M., Rohling, E. J., Grant, K., van der Meer, M. T. J., Schouten, S., Hemleben, C., and Kucera, M.: Millennial-scale variability in Red Sea circulation in response to Holocene insolation forcing, Paleoceanography, 25, PA3203, 
doi:10.1029/2009PA001826, 2010.

Van Campo, E., Duplessy, J. C., and Rossignol-Strick, M.: Climatic conditions deduced from a 150-kyr oxygen isotope-pollen record from the Arabian Sea, Nature, 296, 56-59, 1982.

van der Meer, M. T. J., Baas, M., Rijpstra, W. I. C., Marino, G., Rohling, E. J., Sinninghe Damsté, J. S., and Schouten, S.: Hydrogen isotopic compositions of long-chain alkenones record freshwater flooding of the Eastern Mediterranean at the onset of sapropel deposition, Earth Planet. Sc. Lett., 262, 594-600, 2007.

Veldhuis, M., Kraay, G., Van Bleijswijk, J., and Baars, M.: Seasonal and spatial variability in phytoplankton biomass, productivity and growth in the northwestern Indian Ocean: the southwest and northeast monsoon, 1992-1993, Deep-Sea Res. Pt. I, 44, 425-449, 1997.

Walsh, E., Ingalls, A., and Keil, R.: Sources and transport of terrestrial organic matter in Vancouver Island fjords and the Vancouver-Washington Margin: A multiproxy approach using $\delta^{13} \mathrm{C}_{\text {org }}$, lignin phenols, and the ether lipid BIT index, Limnol. Oceanogr., 53, 1054-1063, 2008.

Wang, Y. J., Cheng, H., Edwards, R. L., Kong, X. G., Shao, X. H., Chen, S. T., Wu, J. Y., Jiang, X. Y., Wang, X. F., and An, Z. S.: Millennial- and orbital-scale changes in the East Asian monsoon over the past 224,000 years, Nature, 451, 1090-1093, 2008.

Weijers, J., Schouten, S., Spaargaren, O., and Sinninghe Damsté, J. S.: Occurrence and distribution of tetraether membrane lipids in soils: Implications for the use of the $\mathrm{TEX}_{86}$ proxy and the BIT index, Org. Geochem., 37, 1680-1693, 2006.
Weikert, H., Edwards, F., and Head, S.: Plankton and the pelagic environment, in: Red Sea (key environments), edited by: Edwards, A. J. and Head, S. M., Pergamon Press, Oxford, 90-111, 1987.

Weldeab, S., Lea, D., Schneider, R., and Andersen, N.: 155,000 years of West African Monsoon and ocean thermal evolution, Science, 316, 1303-1307, 2007.

Winograd, I. J., Coplen, T. B., Landwehr, J. M., Riggs, A. C., Ludwig, K. R., Szabo, B. J., Kolesar, P. T., and Revesz, K. M.: Continuous 500,000-Year Climate Record from Vein Calcite in Devils Hole, Nevada, Science, 258, 255-260, 1992.

Winter, A., Almogi-Labin, A., Erez, Y., Halicz, E., Luz, B., and Reiss, Z.: Salinity tolerances or marine organisms deduced from Red Sea Quaternary record, Mar. Geol., 53, M17-M22, 1983.

Whiteman, A.: The Geology of the Sudan Republic, Clarendon Press, Oxford, 290 pp., 1971.

Wu, G. J., Pan, B. T., Guan, Q. Y., Liu, Z. G., and Li, J. J.: Loess record of climatic changes during MIS5 in the Hexi Corridor, northwest China, Quatern. Int., 97-8, 167-172, 2002.

Yuan, D., Cheng, H., Edwards, R., Dykoski, C., Kelly, M., Zhang, M., Qing, J., Lin, Y., Wang, Y., Wu, J., Dorale, J. A., An, Z., and Cai, Y.: Timing, Duration, and Transitions of the Last Interglacial Asian Monsoon, Science, 304, 575-578, 2004. 